\title{
Analysis on College English Teaching Reform and Development Under the Background of Internet Plus
}

\author{
Xue $\mathrm{Li}^{*}$ \\ School of Foreign Languages, Dalian Jiaotong University, Dalian, Liaoning 116028, China \\ "Corresponding author. Email: lixue_sherry@djtu.edu.cn
}

\begin{abstract}
The advent of the Internet era has brought more teaching and learning resources to college English teaching, which will undoubtedly bring new opportunities to college English teaching. As long as it is properly used, the quality and efficiency of college English teaching will be constantly improved. Based on the background of Internet plus, this paper focuses on the college English teaching reform and development path. The author first analyses the necessity of college English teaching reform under the Internet background and the advantages of internet bring to college English, and then discuss the current situation of college English teaching under the background of internet plus, finally put forward the new path of development, aiming to promote better development of college English education.
\end{abstract}

Keywords: Internet plus, college English teaching, reform, development

\section{INTRODUCTION}

With the rapid development of Internet technology, the Internet has been deeply integrated with various industries, creating a new ecology. College English is an important course in college education, in the age of the Internet, also needs to insist on advancing with the times of teaching, timely using Internet resources for college English teaching reform. New teaching reform and development path should be explored in order to optimize all sorts of problems existing in college English teaching, prompting the advancement of college English teaching reform more smoothly, which will lay a foundation for the continuous improvement of the comprehensive English ability and quality of all college students.

\section{THE NECESSITY OF COLLEGE ENGLISH TEACHING REFORM UNDER THE BACKGROUND OF INTERNET PLUS}

\subsection{Meet the Learning Needs of Diversified Subjects}

In the current "Internet plus" era, the fundamental purpose of the design and reform of college English teaching system is to better train modern talents and improve students' comprehensive ability in English. With the help of network technology, media technology and digital technology, teachers and students can better collect English learning materials, and expand the curriculum resources of college English [1], further enrich the learning content of college English courses, so as to adapt to the actual needs of the current society and jobs. In addition, in the teaching mode of a large class, there are hundreds of students in one class, so the teacher cannot know the individual English learning situation of each student. However, through the current online teaching and online homework acceptance, the teacher can know the learning characteristics and learning deficiencies of each student in a more specific way. Thus teachers will adopt targeted teaching strategies to improve students' English learning level, which can not only greatly meet the needs of diversified learning subjects in the class, but also make the learning of college English courses more personalized.

\subsection{Better Conform to the Teaching Reform and Social Development Trend}

In the course of quality teaching reform in China, higher requirements are put forward for the teaching and reform of college English courses. In order to change the traditional English teaching shortcomings that focus on test only but ignore the communication ability, English teaching under the Internet should create an English learning and communication atmosphere, make full use of students' fragmented time to create English life scene, promote the idea of using fragmented time to learn English by micro-film, video, and so on [2]. College English curriculum reform is also the general trend. In the era of Internet plus, strengthening the design and reform of college English digital network teaching not only accelerates the reform of college English courses and teaching methods, but also enables college English teaching and talent training in the new era to conform to the development trend of society and meet the needs of social and talent development. 


\section{THE ADVANTAGES INTERNET BRINGS TO COLLEGE ENGLISH TEACHING}

\subsection{Enriching Teaching Resources}

In the process of traditional college English teaching, educational resources always show a strong closed characteristic, and can only go to the library, laboratory and other places to obtain teaching resources. However, in the "Internet plus" environment, the teaching resources show a strong open character, and can obtain high-quality education resources from different regions and countries anytime and anywhere, so as to share resources to the maximum extent. At the same time, besides paper textbooks, teaching resources also exist in the form of various electronic resources [3], such as network platforms and online test banks, which make educational resources in a three-dimensional state, which undoubtedly provides a favourable opportunity for students' personalized learning.

\subsection{New Form of Teaching Organization}

In the traditional college English teaching process, teachers always adopt a single explanation teaching mode, so that students can only passively receive knowledge through textbooks and classes, and the whole learning process can not reflect any independent characteristics, which will limit the development of students' interest in English learning. However, in the "Internet plus" environment, teaching is no longer confined to the classroom, but has evolved into an innovative mode combining online classroom with students' independent learning, leaving sufficient space for students' independent learning and exploration, which can effectively maintain their interest in learning. Therefore, in modern college English teaching, "mobile Internet + classroom" has become an inevitable means of teaching, and through bullet screen, micro-teaching assistant and other software, to enhance the communication between teachers and students, make a more convenient management for students, thus create a stronger learning atmosphere. After class, students can conduct more targeted learning in the form of online courses based on their own learning facts, which can improve students' independent learning ability and English learning effect [4].

\subsection{Repositioning the Teaching Role}

In the traditional college English teaching process, teachers always play the single role of knowledge imparting. However, with the advent of the Internet era, students have more and more extensive ways to acquire knowledge, and the role of teachers also needs to change constantly. Specifically, the shift is from knowledge imparting to designers, facilitators, helpers, and participants. For the role of designer, it refers to the design of personalized learning mode for students based on their differences in preferences and motivations. For the role of facilitator, it means to grasp the actual learning situation of students through formative assessment first, and guide students to complete the pre-set learning tasks on this basis As for the role of helper, it refers to paying attention to students' actual habit status in time. When they cannot break through the learning dilemma, they need to clarify the reasons and provide targeted help to students. In terms of the role of participants, it means that after organizing teaching activities in class, teachers and students need to participate in teaching activities in a timely manner to complete teaching tasks. After class, we should communicate and contact with students in time, and participate in their after-class learning in time to become students' learning partners. It is believed that only after teachers reposition their teaching roles can they play different teaching roles in different teaching links [5], so that students can truly become the subject of learning, better mobilize their enthusiasm to participate in learning, and lay a foundation for the continuous improvement of students' comprehensive English ability and accomplishment.

\section{CURRENT SITUATION OF COLLEGE ENGLISH TEACHING UNDER THE BACKGROUND OF INTERNET PLUS}

\subsection{Insufficient Network Resources}

Although China has financial support in the network teaching resources, but the network teaching resources cannot fully meet the needs of college English teaching. The state has invested more funds and equipment, but there is a mismatch between teaching content and resources. Teaching content is not updated in time, content is relatively backward, imitation is in the majority. Inadequate English teaching resources seriously affect the efficiency and enthusiasm of students in learning English. Even though some colleges and universities have invested a lot of money in English resource construction, they have failed to realize the development goal of resource sharing, which leads to repeated construction among colleges and universities and reduces the efficiency of resource integration.

\subsection{Shortage of Professional Teachers}

Under the influence of the Internet, the teaching relationship between teachers and students has changed, requiring teachers to understand and master modern science and technology while teaching, and to develop new ways and methods conducive to students' multimedia learning. But at present, college English or other network teaching in our country is mostly undertook by the English 
teachers, lack of network English teaching professionals. Therefore, how to use the Internet for efficient learning in college English teaching and how to combine innovative technologies with teaching methods have become the main challenge facing teachers and students of college English learning in China.

\subsection{Unchanged Teaching Concept}

At present, the majority of colleges and universities still use the traditional and old-fashioned way to conduct English teaching, without giving full play to the role of Internet English teaching. It is believed that college English network teaching only converts teaching materials into multimedia presentation, and there is no efficient information exchange between teachers and students, so the teaching quality is difficult to be improved. Internet teaching is not simply to change the teaching method, but to fundamentally change the traditional teaching model. Internet teaching should be a transformation of teaching philosophy, to truly achieve high-quality network English teaching [6]. College English learning lacks a certain basis of concept management, and teachers have not made proper analysis and reflection on the teaching results. Teachers only pay attention to the results of teaching and ignore the quality of teaching, which leads to that even if students have a convenient Internet platform, they will be less enthusiastic about learning for students with a relatively weak English foundation, thus increasing the achievement and distance between students.

\subsection{Students' Less Interested in Learning Online Courses}

In the stage of college education and learning, there are high requirements for students' independent learning ability and initiative. However, in the design and implementation process of college English digital online courses, many college students lack scientific cognition for online courses and low learning enthusiasm. For example, many college students will skip classes and sleep in the course of online listening, or when the teacher is not paying attention to, browse irrelevant things, play games, listen to music and whisper more and more scene. To some extent, this shows that students lack interest in the digitalized network teaching system and reform of college English, and they are unable to fully mobilize the enthusiasm of learning English in current online courses and video teaching. The current network technology and digital technology cannot play an effective role in English teaching. The lack of students' enthusiasm for Internet learning directly leads to the disconnection between college English classes and practical application. As a result, a large number of students who are eager to learn English turn to social English training institutions for secondary intensive learning when they are faced with the need of actual English communication.

\section{THE DEVELOPMENT PATH OF COLLEGE ENGLISH UNDER THE BACKGROUND OF INTERNET PLUS}

\subsection{Reform of the Teaching Material}

At present, the textbooks recommended by the ministry of education are basically used in colleges and universities in China. The advantages of this textbook are very obvious. For example, the auxiliary materials are perfect and the contents are organized and reliable. Therefore, it is necessary for colleges and universities to choose interesting, practical and professional textbooks based on different majors, so that students can acquire practical English knowledge, so as to get better employment in the future.

\subsection{Reform of the Curriculum Plan}

Colleges and universities often give unified teaching plans for each semester of college English teaching in order to provide effective basis for teachers' teaching. Although the formulation of this teaching plan can ensure the smooth progress of teaching, it will also limit the teaching progress and content of teachers, making teachers' teaching in a state of tension, difficult to mobilize teachers' teaching initiative and creativity. It is necessary to change the education program under the background of the new period. What you need to do is to make the direction of teaching planning, and then give teachers flexible lesson preparation, teaching opportunity and space. Only in this way can teachers' teaching enthusiasm be improved to the maximum extent, and students can gain more language knowledge and constantly improve their language ability.

\subsection{Reform of the Teaching Mode}

In the reform of college English teaching under the Internet environment, the reform of teaching mode is extremely important, which needs to completely transition from "teacher-centered" to "student-centered" [7]. To be specific, innovative micro courses and English films can be applied to teaching, so as to expand the content of listening and speaking teaching, and integrate listening and speaking materials from English-speaking countries into language teaching, so as to better improve students' listening and speaking ability. In terms of students' reading and writing ability, relevant content should also be collected from the Internet to improve students' reading and writing ability. I believe that after continuous teaching guidance, students' interest in English learning will become more and more intense, and the quality of natural English teaching will be improved to a greater extent. 
[3] Cui He, Design and Research on Flipped Classroom Learning in College English Under the Background of "Internet + Education", Ability Wisdom, vol.1, pp.4, 2017.

[4] Ye Rong: Research on the Application of Mobile Learning in English Autonomous Learning, Journal of Sichuan College of Education, vol. 10, pp.26, 2011.

[5] Bruton A, Samuda V., Learner and Teacher Roles in the Treatment of Error in Group Work, RELC Journal, vol. 11, pp. 49- 63, 1980.

[6] Zhou Yun, A Study on College English Smart Teaching Model from the Perspective of Mobile Internet, Modern Educational Technology, vol. 12, pp.79-85, 2016.

[7] Kuaibin and $\mathrm{He}$ Juan, Reflections on the Communicative Approach in College English Teaching, Course Education Research, vol.37, pp. 96-97, 2016.

[8] Salmon, J., and Nyhan, J., Augmented Reality Potential and Type: Towards an Evaluative Framework in Foreign Language Teaching, The Journal of Language Teaching and Learning, vol.1, pp.54, 2013.

[9] Hua Lulu, Chen Lin, Sun Mengmeng, Research on the Improvement of English Learning by Artificial Intelligence, Modern Distance Education, vol.6, pp.27, 2017. comprehensive way. In the society, many English teaching platforms are worthy learning models for college English teaching and design, but the quality of each platform is uneven due to the pursuit of profit maximization. Universities, as public institutions, have the advantages of national policies and social credibility, and should develop their own English teaching platform. At the same time, with the instruction of teachers, students can use fragmented time to carry out daily life English learning. As a comprehensive learning platform, it can provide knowledge and help at any time outside the English classroom [9]. With the help of effective Internet technology and digital technology, the teaching methods and teaching system of college English courses should be innovated to improve the teaching efficiency of college English courses.

\section{REFERENCES}

[1] Michael Negnevitsky, Artificial Intelligence: A Guide to Intelligent System [M], Third Edition, Perason Education Limited, 2012.

[2] Godwin-Jones, R., Augmented Reality and Language Learning: From Annotated Vocabulary to Place-based Mobile Games, Language Learning \& Technology, vol. 3, pp. 9, 2016. 